\author{
Barbara Jędrychowska \\ Mirostaw Piwowarczyk \\ (Wroctaw)
}

\title{
Działalność wrocławskiego Zakładu Historii Edukacji w latach 1999-2009'
}

Wrocławska powojenna pedagogika od początku była ściśle związana z historią wychowania. Kiedy 5 grudnia 1945 r. na Wydziale Humanistycznym Uniwersytetu Wrocławskiego utworzono Zakład Pedagogiki, kierowanie nim powierzono przybyłemu z Uniwersytetu Poznańskiego profesorowi Stanisławowi Tyńcowi, który doktoryzował się (1922) i habilitował (1928) właśnie w tym zakresie. W kwietniu 1949 r. na czele kolejnego powołanego Zakładu - Historii Wychowania i Szkolnictwa, stanął przeniesiony służbowo z Uniwersytetu Jagiellońskiego historyk oświaty, profesor Henryk Barycz. Jego asystentką została absolwentka historii tej uczelni - mgr Mirosława Chamcówna.

Kilka miesięcy później Zakłady te przekształcono w Katedry, a po powrocie w roku 1953 prof. Barycza do Krakowa, na Wydziale Humanistycznym pozostała jedynie Katedra Pedagogiki, prowadzona przez prof. Tyńca. W roku akademickim 1950/1951 znalazła się ona w strukturze nowej jednostki administracyjnej uczelni - Wydziału Filozoficzno-Historycznego. Dwadzieścia lat później Katedrę przekształcono w Instytut (1972), w ramach którego utworzono Zakład Historii Wychowania, z kierownikiem prof. Mirosławą Chamcówną.

Profil prac badawczych prowadzonych początkowo w Zakładach, a następnie Katedrze Pedagogiki wyznaczały przede wszystkim zainteresowania pracowników, ich rze-

\footnotetext{
1 Problematyka, związana z wrocławskim ośrodkiem historii oświaty i wychowania, podejmowana była już we wcześniejszych publikacjach. Część historyczna obecnego tekstu odwołuje się między innymi do prac: Pedagogika wrocławska (wybrane zagadnienia, aktualne badania), pod red. B. Potyrały, w: Acta Universitatis Wratislaviensis, nr 928, „Prace Pedagogiczne” LIX, Wrocław 1986; M. Chamcówna, J. Kargul, Katedra i Instytut Pedagogiki Uniwersytetu Wroclawskiego w latach 1945-1989, w: Acta Universitatis Wratislaviensis, nr 1270, „Prace Pedagogiczne” LXXXVII, Wrocław 1991; A. Haratyk, J. Szablicka-Żak, Aktualny stan badań w Zakładzie Historii Oświaty $i$ Wychowania Uniwersytetu Wrocławskiego oraz perspektywy rozwoju - a także: B. Jędrychowska, M. Piwowarczyk, Współpraca Zakładu Historii Oświaty i Wychowania Instytutu Pedagogiki Uniwersytetu Wroctawskiego z naukowymi ośrodkami zagranicznymi (1989-1997), w: Historia wychowania w XX w. Dorobek i perspektywy, red. T. Gumuła, J. Krasuski, S. Majewski, Kielce 1998; Ocalić od niepamięci, red. J. Szablicka-Żak, Kraków 2002.
} 
telna wiedza i naukowe predyspozycje, ale także ograniczenia, wynikające z ówczesnej polityki państwa. Ponieważ w tym okresie wrocławską historię oświaty i wychowania reprezentowali wybitni przedstawiciele tej dyscypliny, w dużej mierze określała ona kierunki i poziom działalności naukowej Zakładów i późniejszej Katedry.

Podejmowane wówczas badania z tego zakresu koncentrowały się wokół problematyki polskiego oświecenia, a zwłaszcza Komisji Edukacji Narodowej oraz szkolnictwa różnowierczego i szkolnictwa na Śląsku. W latach 1949-1972 (do chwili utworzenia Instytutu) dziewięć osób w Katedrze Pedagogiki uzyskało stopień naukowy doktora, przygotowując rozprawy z historii oświaty i wychowania, co stanowiło blisko 40\% wszystkich doktoratów w tym okresie ${ }^{2}$. Ich promotorami byli prof. Tync i prof. Chamcówna. W tej grupie doktorów znalazła się między innymi dr Zofia Maresz (1963 r.), absolwentka studiów historycznych Uniwersytetu Jagiellońskiego, po 1956 r. pracownik naukowy wrocławskiej Katedry Pedagogiki, a następnie Zakładu Historii Oświaty i Wychowania w Instytucie Pedagogiki. W swoich początkowych badaniach kontynuowała nurt oświeceniowy, późniejsze zainteresowania sytuując głównie w okresie pozytywizmu.

Skład osobowy Zakładu, funkcjonującego w ramach Instytutu, zmieniał się, zróżnicowana również była problematyka badawcza, podejmowana przez jego pracowników. Profesor Mirosława Chamcówna nie narzucała swoim asystentom i adiunktom obszaru naukowych dociekań, pozwalając, aby były one zgodne z ich zainteresowaniami. Jedynym, wspólnie podjętym przez część zespołu przedsięwzięciem, była praca nad tematem: „Nauczyciele szkół średnich w XIX i XX w. jako grupa społeczna i ich wkład w kulturę polską", realizowanym od 1986 r. w ramach ogólnopolskiego problemu badawczego: „Polska kultura narodowa, tendencje rozwojowe i percepcja”. Efekty kilkuletnich badań zostały opublikowane w 1995 r. w dziele zbiorowym, opracowanym pod redakcją prof. Mirosławy Chamcówny oraz dr Stefanii Walasek ${ }^{3}$, która w roku następnym już jako dr habilitowany, przejęła kierowanie Zakładem.

Po śmierci Pani Profesor w roku 2000 Zakład przyjął nazwę: Zakład Historii Edukacji i jest jednym z ośmiu zakładów Instytutu Pedagogiki, który usytuowany jest na Wydziale Nauk Historycznych i Pedagogicznych Uniwersytetu Wrocławskiego. Obecnie w skład Zakładu wchodzą: prof. dr hab. Stefania Walasek, dr hab. Barbara Jędrychowska, dr Aleksandra Bilewicz, dr Anna Haratyk, dr Jolanta Szablicka-Żak i dr Mirosław Piwowarczyk.

Profesor Stefania Walasek, kierując Zakładem od 1 września 1996 r., równocześnie była Zastępcą Dyrektora Instytutu Pedagogiki ds. studiów zaocznych. W 1999 r. została wybrana na stanowisko Dyrektora Instytutu, a po ukończeniu kadencji w 2005 r. podjęła się pełnienia funkcji Prodziekana Wydziału Nauk Historycznych i Pedagogicznych ds.

2 Do tej liczby należałoby włączyć co najmniej 4 rozprawy doktorskie z zakresu historii oświaty i wychowania, obronione w latach 1973-1976, ponieważ prace badawcze ich autorzy podejmowali zapewne przed 1972 r. W okresie 1973-1989 w Instytucie wypromowano 11 doktorów, którzy zrealizowali badania w tej dziedzinie, ale stanowiły one już tylko około $18 \%$ wszystkich obszarów badawczych pedagogiki, zaprezentowanych w rozprawach.

3 Acta Universitatis Wratislaviensis, nr 1736, „Prace Pedagogiczne” CVIII, Wrocław 1995. 
Dydaktyki ${ }^{4}$. Jest Ona także uczestnikiem wielu komisji i zespołów naukowych i redakcyjnych, m.in.: członkiem Rady Naukowej Centrum Edukacji Nauczycielskiej Uniwersytetu Wrocławskiego (od 1.10.2002 do 31.8.2005), członkiem Rady Naukowej X Jubileuszowej Edycji Konkursu Wiedzy o Uniwersytecie Jagiellońskim (od 1.10.2002 do 31.8.2005), członkiem Kolegium Redakcyjnego czasopisma „Przegląd Historyczno-Oświatowy (od 1.1.2003), Kolegium Redakcyjnego czasopisma „Pedagogika” (Vilnius-Opole, od 2003 r.), członkiem Komitetu Redakcyjnego międzynarodowego czasopisma „Czech-Polish Historical and Pedagogical Journal” (od kwietnia 2009), redaktorem serii wydawniczej Prace Pedagogiczne, Acta Universitatis Wratislaviensis (od 27.11.2002).

Dużą aktywnością w organizacjach naukowych wyróżnia się dr hab. Barbara Jędrychowska, która jest wieloletnim członkiem Polsko-Rosyjskiej Komisji Historycznej PAN-RAN, Komisji Badań nad Historią Syberii Komitetu Historii Nauki i Techniki PAN i Towarzystwa Historii Edukacji. Wieloletnią działalność organizacyjną prowadzą najmłodsi pracownicy Zakładu - dr Anna Haratyk oraz dr Mirosław Piwowarczyk. A. Haratyk od 2004 r. jest Zastępcą Dyrektora Instytutu Pedagogiki ds. studiów niestacjonarnych i opiekunem Koła Naukowego Studentów Pedagogiki „ETNO”, a także organizatorem ogólnopolskich wyjazdów studyjnych dla pracowników naukowych i studentów na Ukrainę, cieszących się z coraz większym zainteresowaniem. Ich ideą przewodnią jest poznawanie tradycji, kultury i oświaty polskiej na kresach dawnej Rzeczypospolitej6. Dr Mirosław Piwowarczyk pełni od 1 września 1999 r. funkcję Zastępcy Dyrektora Instytutu Pedagogiki ds. studiów zaocznych, a od 1 września 2002 - nieprzerwanie Zastępcy Dyrektora ds. studiów stacjonarnych. Jest także m.in. członkiem Rady Naukowej Centrum Edukacji Nauczycielskiej Uniwersytetu Wrocławskiego (od 1.10.2005), członkiem Rady Kolegium Międzywydziałowych Indywidualnych Studiów Humanistycznych (od 2008) i członkiem Komitetu Redakcyjnego międzynarodowego czasopisma „Czech-Polish Historical and Pedagogical Journal” (od kwietnia 2009).

Stawiając sobie za cel integrację środowiska historyków oświaty, w styczniu 2008 r. utworzyliśmy przy Instytucie Pedagogiki Koło Historyków Edukacji (w ramach ogólnopolskiego Towarzystwa Historii Edukacji) ${ }^{7}$. Tworzą je nie tylko pracownicy Zakładu, lecz także naukowcy z innych wydziałów Uniwersytetu Wrocławskiego oraz z Uniwersytetu Opolskiego (prof. dr hab. Eleonora Sapia-Drewniak) i Dolnośląskiej Szkoły Wyż-

${ }^{4}$ Funkcję Zastępcy Dyrektora Instytutu Pedagogiki ds. studiów zaocznych pełniła od 1.10.1985 do 31.9.1988, następnie od 1.10.1996 do 31.8.1998. Od 1.9.1998 do 31.8.1999 pełniła funkcję Zastępcy Dyrektora Instytutu Pedagogiki ds. nauki. Stanowisko Dyrektora Instytutu sprawowała od 1.9.1999 do 31.8.2005. Od 1.9.2005 pełni funkcję Prodziekana ds. Dydaktyki Wydziału Nauk Historycznych i Pedagogicznych.

${ }^{5}$ Koło pod przewodnictwem A. Haratyk prowadzi działalność na rzecz Instytutu Pedagogiki i środowiska, organizuje obozy naukowe w kraju i poza jego granicami (Podhale, Kaszuby, Ukraina, Czechy) i konferencje naukowe. Członkowie Koła biorą również czynny udział w konferencjach, wygłaszając referaty.

${ }^{6}$ Wyjazdy, w których uczestniczyli pracownicy naukowi z wielu uczelni w Polsce i liczni studenci odbyły się w 2001, 2002, 2008 i 2009 r. (Zachodnia Ukraina, Podole, Zakarpacie, Huculszczyzna, Bukowina, Mołdawia).

7 Przewodniczącą Koła jest prof. dr hab. Stefania Walasek, a sekretarzem dr Mirosław Piwowarczyk. Strona internetowa Koła: http://www.pedagogika.uni.wroc.pl, (zakładka THE); adres e-mail: wkthe@dawid. uni.wroc.pl. 
szej (prof. dr hab. Jerzy Kochanowicz). Koncentrujemy wspólne badania na problematyce szkolnictwa i oświaty na Śląsku po 1945 r.

\section{Problematyka badawcza (1999-2009) ${ }^{8}$}

W ostatnich dziesięciu latach Zakład rozwijał się naukowo - pracownicy zdobywali kolejne stopnie naukowe ${ }^{9}$ i powiększali swój naukowy dorobek. W tym okresie wykrystalizowały się też zainteresowania i plany badawcze najmłodszych członków Zakładu, czemu sprzyjały liczne kwerendy archiwalne i biblioteczne, zwłaszcza poza granicami kraju.

Dorobek Zakładu jest stosunkowo rozległy i zróżnicowany, chociaż jego pracownicy w działalności naukowej skupiają się głównie na XIX i XX w. Ustalił się obszar geograficzny naszych prac badawczych: XIX-wieczna Rosja (B. Jędrychowska), ziemie północno-wschodnie Rzeczypospolitej w XIX w. (S. Walasek, B. Jędrychowska), II Rzeczypospolita (S. Walasek, J. Szablicka-Żak, M. Piwowarczyk), Wielkopolska (M. Piwowarczyk) oraz Galicja (A. Haratyk). Mimo że prowadzone badania mają charakter indywidualny, łączy nas zainteresowanie aktywnością małych społeczności lokalnych, funkcjonujących w wielokulturowym środowisku. Coraz częściej w swoich rozprawach naukowych podejmujemy problematykę pozaszkolną. Koncentrujemy uwagę na roli edukacyjnej różnych instytucji w XIX i w XX w.: rodziny, przedszkola, organizacji społecznooświatowych oraz kulturalnych. Egzemplifikacją tych zainteresowań - badań są publikowane liczne prace, rozprawy, recenzje naukowe.

Kierunek badań ostatniego dziesięciolecia prof. dr hab. Stefanii Walasek wyznaczają problemy oświaty i szkolnictwa w XIX i XX w., m.in. odnoszące się do guberni wileńskiej. Z tego zakresu opublikowana została monografia pt. Polska oświata w guberni wileńskiej w latach 1864-1915 (wyd. 1, Kraków 2002, wyd. 2. Kraków 2003), a także wiele artykułów, wśród których na szczególną uwagę zasługują: Nauczanie elementarne w guberni wileńskiej w latach 1871-1915 ${ }^{10}$, Tajne szkolnictwo polskie i oświata $w$ Wileńskim Okręgu Szkolnym w latach 1863-191511, Nauczycielki tajnej oświaty w Okręgu

\footnotetext{
${ }^{8}$ W 1998 r. ukazała się praca pod redakcją T. Gumuły, J. Krasuskiego, S. Majewskiego, Historia wychowania $w$ XX w. Dorobek i perspektywy (Kielce 1998), gdzie zaprezentowany został dorobek i dokonania wrocławskich historyków oświaty. W pracy zamieszczone zostały artykuły J. Szblickiej-Żak i A. Haratyk: Aktualny stan badań w Zakładzie Historii Oświaty i wychowania Uniwersytetu Wrocławskiego oraz perspektywy ich rozwoju oraz B. Jędrychowskiej i M. Piwowarczyka: Wspótpraca Zakładu Historii Oświaty $i$ Wychowania Instytutu Pedagogiki Uniwersytetu Wrocławskiego z naukowymi ośrodkami zagranicznymi (1989-1997), stąd prezentowany aktualnie dorobek Zakładu (jego najważniejsze dokonania) obejmuje okres ostatniego dziesięciolecia (1999-2009).

${ }^{9}$ W październiku 1999 r. stopień doktora uzyskali - A. Haratyk i M. Piwowarczyk. W 2005 roku habilitowała się B. Jędrychowska.

${ }^{10}$ Nauczanie elementarne $w$ guberni wileńskiej w latach 1871-1915, w: Wokót „Syzyfowych prac”: problemy edukacji wiejskiej w Polsce w XIX i XX wieku, red. M.Meducka, Kielce 1999.

${ }^{11}$ Tajne szkolnictwo polskie $i$ oświata $w$ Wileńskim Okręgu Szkolnym w latach 1863-1915, Seminaria Naukowe Wrocławskiego Towarzystwa Naukowego. A. [nr 1], Wrocław 1999.
} 
Szkolnym Wileńskim w latach 1864-191512, Rola oświaty dorostych na ziemiach polskich w XIX i na poczatku XX w. ${ }^{13}$, Edukacja dzieci i dorostych w spoteczeństwie wielokulturowym guberni wileńskiej w XIX $i$ na poczatku XX wieku ${ }^{14}$, Szkolnictwo i oświata na ziemiach polskich $w$ XIX $i$ na poczatku $X X$ wiek ${ }^{15}$ i Nauczyciele $i$ ich rola $w$ edukacji społeczeństwa byłej guberni wileńskiej w XIX i na początku XX wieku ${ }^{16}$.

Osobny temat stanowiły osiągnięcia badawcze w zakresie szkolnictwa i oświaty na ziemiach północno-wschodnich II Rzeczypospolitej (szkolnictwo polskie oraz oświata i szkolnictwo mniejszości narodowych). Oprócz monografii pt. Szkolnictwo powszechne na ziemiach pótnocno-wschodnich II Rzeczypospolitej (1915-1939) (Kraków 2006), zaliczyć do nich należy artykuły i rozdziały w pracach zbiorowych: Problemy polskiego średniego szkolnictwa ogólnokształcacego na Łotwie w latach 1918-194017, Prywatne szkolnictwo na ziemiach Nowogródzkiego i Wileńskiego KOS w II RP ${ }^{18}$, Relacje polsko-litewskie i polsko-białoruskie na przykładzie szkolnictwa $w$ województwach pólnocno-wschodnich II RP ${ }^{19}$, Nauczyciele szkół powszechnych w województwach północno-wschodnich $w$ latach 1915-1926 20, Edukacyjne aspiracje wielonarodowościowej społeczności na przykładzie ziem pótnocno-wschodnich II Rzeczypospolitej ${ }^{21}$, Towarzystwa i organizacje oświatowe na ziemiach pótnocno-wschodnich ze szczególnym uwzględnieniem Wilna ${ }^{22}$ i Education of the Jewish Community In Vilnius in the years 1918-193923.

${ }^{12}$ Nauczycielki tajnej oświaty w Okręgu Szkolnym Wileńskim w latach 1864-1915, w: Partnerka. Matka. Opiekunka. Status kobiety w dziejach nowożytnych od XVI do XX wieku, red. K.Jakubiak, Bydgoszcz 2000.

${ }_{13}$ Rola oświaty dorostych na ziemiach polskich $w$ XIX i na początku XX w., „Przegląd Historyczno-Oświatowy" $2000 \mathrm{nr} 1-2$.

${ }^{14}$ Edukacja dzieci i dorosłych $w$ spoleczeństwie wielokulturowym guberni wileńskiej w XIX $i$ na początku XX wieku, w: Edukacja wobec wielokulturowości. Księga jubileuszowa ofiarowana profesorowi Januszowi Sztumskiemu, red. M. Janukowicz, K. Rędziński, Częstochowa 2001/2002.

${ }_{15}$ Szkolnictwo $i$ oświata na ziemiach polskich $w$ XIX i na początku XX wieku, w: Edukacja, państwo, naród w Europie Środkowej $i$ Wschodniej XIX i XX w., red. A. Bilewicz, R. Gładkiewicz, S. Walasek, Wrocław 2002.

${ }^{16}$ Nauczyciele i ich rola w edukacji społeczeństwa byłej guberni wileńskiej w XIX i na poczatku XX wieku, w: Edukacja: konteksty historyczno-pedagogiczne, red. nauk. M. Piwowarczyk, Kraków 2007.

${ }_{17}$ Problemy polskiego średniego szkolnictwa ogólnokształcacego na Łotwie w latach 1918-1940, „Przegląd Historyczno-Oświatowy" 2002, nr 3-4.

${ }_{18}$ Prywatne szkolnictwo na ziemiach Nowogródzkiego i Wileńskiego KOS w II RP, w: Funkcja prywatnych szkół średnich w II RP, red. E.J. Kryńska, Białystok 2004.

${ }_{19}$ Relacje polsko-litewskie i polsko-białoruskie na przykładzie szkolnictwa $w$ województwach północno-wschodnich II RP, w: Edukacja w społeczeństwie wielokulturowym, red. K. Rędziński, Częstochowa 2004.

${ }^{20}$ Nauczyciele szkót powszechnych $w$ województwach pótnocno-wschodnich w latach 1915-1926, ,, Rozprawy z dziejów oświaty" t. XLIII (2004).

${ }^{21}$ Edukacyjne aspiracje wielonarodowościowej społeczności na przykładzie ziem pótnocno-wschodnich II Rzeczypospolitej, w: W'́ród ,swoich” i „obcych”. Rola edukacji w społeczeństwach wielokulturowych Europy Środkowej (XVIII-XX w.), red. nauk. S.Walasek, Kraków 2006.

${ }^{22}$ Towarzystwa $i$ organizacje oświatowe na ziemiach pótnocno-wschodnich ze szczególnym uwzględnieniem Wilna, w: Z dziejów oświaty na ziemiach polskich w XIX i XX wieku. Studia i szkice, red. M.Pękowska, Kielce 2007.

${ }^{23}$ Education of the Jewish Community In Vilnius in the years 1918-1939, w: "Czech-Polish historical and pedagogical journal" Volume 1, Brno 2009. 
Odrębny kierunek zainteresowań badawczych profesor S. Walasek stanowi problematyka dotycząca opieki nad dzieckiem i młodzieżą w XIX i XX w. Kwestiom tym poświęcona została praca zbiorowa pod Jej redakcją pt. Opieka nad dziećmi i młodzieżą. Studia z dziejów oświaty w XX wieku (Kraków 2008), w której zamieściła własny rozdział: Opieka nad dziećmi i młodzieża w Wilnie (1900-1940).

Ważnym nurtem badań S.Walasek jest również polski regionalizm w XIX i XX w. oraz zagadnienia związane $\mathrm{z}$ edukacją obywatelską $\mathrm{w}$ społeczeństwie wielokulturowym $^{24}$.

Aktualnie przedmiotem Jej dociekań badawczych stała się działalność społeczno-pedagogiczna Cecylii Plater-Zyberkówny, a także tworzenie i funkcjonowanie ochronek, ogródków freblowskich i przedszkoli w XIX w. oraz II Rzeczypospolitej ${ }^{25}$.

Działalność cywilizacyjna dziewiętnastowiecznych polskich zesłańców na Syberii to sfera dociekań badawczych dr hab. Barbary Jędrychowskiej. Przedmiotem Jej szczególnych zainteresowań jest działalność syberyjskich wygnańców na polu nauki, oświaty i wychowania, kultury oraz gospodarki Rosji. Opublikowała z tego zakresu dwie monografie: Polscy zestańcy na Syberii. Działalność pedagogiczna, oświatowa i kulturalna (1830-1883) (Wrocław 2000) i Wszystkim obcy i cudzy. Feliks Zienkowicz i jego listy z Syberii 1864-1882 (Wrocław 2005). Rozprawa ta, podejmująca m.in. problematykę rosyjskiego szkolnictwa w XVIII i XIX w. oraz polskich zesłańców jako nauczycieli i wychowawców, stanowiła podstawę habilitacji w roku 2005. W nurcie zainteresowań badawczych B.Jędrychowskiej znajduje się także problematyka szkolnictwa na obszarach Wileńskiego Okręgu Naukowego (1803-1832), podjęta m.in. w artykule pt. Wychowanie patriotyczne i obywatelskie w szkolnictwie polskim pod zaborem rosyjskim (Wileński Okręg Naukowy ${ }^{26}$. W przygotowaniu są również monografie szkół średnich WON (Świsłocz, Nowogródek, Brześć Litewski). Do istotnych pod względem obszaru badawczego należy artykuł pt. $Z$ doświadczeń badawczych historyka oświaty na Wschodzie (ziemie litewsko-białoruskie i Syberia Wschodnia)27, w którym autorka prezentuje swoje

${ }^{24}$ Edukacja w spoleczeństwie wielokulturowym na przykładzie zaboru rosyjskiego na przełomie XIX $i$ XX wieku w: Idea wielokulturowości w edukacji, red. K. Rędziński, B. Snoch, J. Żuraw, Prace Naukowe WSP w Częstochowie. Pedagogika XII, Częstochowa 2003; Polski regionalizm w XIX i XX wieku (do 1939 roku), $\mathrm{w}$ : Misto historie a ulowa uciteledejepisu pri formowani multikulturni spolecnosti (The role of history teachers in the sharping of a multicultural society), red. J. Vaculik, J. Mihola, Brno 2003; Wielokulturowość w aspekcie historycznym, w: Edukacja - różnica i tożsamość, red. K. Rędziński i I. Wagner, Częstochowa 2004/2005; Rozważania na temat wychowania obywatelskiego w polskiej literaturze pedagogicznej II Rzeczypospolitej, w: Historyczne konteksty edukacji obywatelskiej w spoleczeństwach wielokulturowych, pod red. nauk. A. Szerlag, Kraków 2007; Regionalizm - przeszłość i współczesność - wyzwania dla edukacji, w: Nauki pedagogiczne w Polsce: dokonania, problemy, współczesne zadania, perspektywy, red. T. Lewowicki, M.J. Szymański przy współpracy R. Kwiecińskiej, S. Kowala, Kraków 2004; Edukacja podstawą kształcenia świadomości narodowej (XIX-XX wiek), w: Edukacja ku wartościom, red. A. Szerląg, Kraków 2004.

${ }^{25}$ Frobelovske materske skoly v Polsku a Halici v rokach 1867-1914, w: „Predskolska Vychova” nr 2, Bratysława 1999.

${ }^{26}$ Wychowanie patriotyczne i obywatelskie $w$ szkolnictwie polskim pod zaborem rosyjskim (Wileński Okręg Naukowy), w: Historyczne aspekty edukacji obywatelskiej w spoleczeństwie wielokulturowym, red. A.Szerląg, Kraków 2007.

${ }^{27}$ Z doświadczeń badawczych historyka oświaty na Wschodzie (ziemie litewsko-białoruskie $i$ Syberia Wschodnia), w: Źródła w badaniach naukowych historii edukacji, red. nauk. W. Szulakiewicz, Toruń 2003. 
doświadczenia w pracy naukowej, odnoszące się do kwerend archiwalnych i bibliotecznych w Moskwie, Petersburgu, Wilnie i Grodnie.

W omawianym okresie dr Aleksandra Bilewicz-Lewczuk zajęła się współczesną problematyką edukacji ludzi starszych i działalnością Uniwersytetu Trzeciego Wieku we Wrocławiu. Efektem Jej prac badawczych są dwie monografie: Uniwersytet Trzeciego Wieku we Wrocławiu w latach 1976-2001. Cz. $1 .{ }^{28}$ i Uniwersytet Trzeciego Wieku we Wrocławiu w latach 1976-200729. A. Bilewicz brała też udział w przygotowaniu pracy zbiorowej pt. Edukacja, państwo, naród $w$ Europie Środkowej $i$ Wschodniej XIX $i X X w^{30}$

Tematyka opieki nad dzieckiem osieroconym i zaniedbanym w Galicji stała się problemem badawczym dr Anny Haratyk, która w sposób szczególny zajęła się zagadnieniami dotyczącymi udziału władz państwowych i krajowych, Kościoła oraz społeczeństwa w organizowaniu pozaszkolnych form opieki nad dziećmi i młodzieżą, a także prezentacją dokonań społeczników i pedagogów, zaangażowanych w tworzenie różnych form opieki. Wynikiem Jej pracy są dwie monografie: Rozwój opieki nad dziećmi i młodzieża w Galicji doby autonomicznej (Wrocław 2002) i Udziat społeczeństwa galicyjskiego w opiece nad dziećmi ubogimi i osieroconymi (1867-1914) (Kraków 2007). Przygotowała również kilka artykułów, dotyczących tego kręgu problemów m.in.: Udziat galicyjskiego Kościoła katolickiego w pracach opiekuńczo-wychowawczych ${ }^{31}$, Opieka prawna nad sierotami $w$ Galicji doby autonomicznej ${ }^{32}$, Udziat społeczeństwa krakowskiego w niesieniu pomocy dzieciom w II połowie XIX i na początku XX wieku ${ }^{33}$, Placówki opieki nad dziećmi w Galicji doby autonomicznej ${ }^{34}$, Uniwersytet Wakacyjny w Zakopanem jako jedno ze źródeł łączności i edukacji kulturalnej Polaków w okresie zaborów ${ }^{35}$.

Od kilku lat dr Haratyk prowadzi intensywne badania, których przedmiotem jest tradycyjne wychowanie domowe w rodzinach polskich i ruskich górali karpackich w XIX i początkach XX w. Ich celem jest poznanie procesu, charakteru i efektów tradycyjnego wychowania $\mathrm{w}$ rodzinie, ukazanie podobieństw i różnic występujących w tym procesie w poszczególnych grupach etnicznych, zamieszkujących obszar Karpat (Podhalanie, Hu-

\footnotetext{
28 Uniwersytet Trzeciego Wieku we Wrocławiu w latach 1976-2001. Cz. 1, Wrocław 2001.

29 Uniwersytet Trzeciego Wieku we Wrocławiu w latach 1976-2007, Kraków 2009.

${ }^{30}$ Edukacja, państwo, naród w Europie Środkowej $i$ Wschodniej XIX i XX w., red. A. Bilewicz, R. Gładkiewicz, S. Walasek, Wrocław 2002.

31 Udzial galicyjskiego Kościoła katolickiego w pracach opiekuńczo-wychowawczych, w: Galicja i jej dziedzictwo. Opieka nad dzieckiem w Galicji, t. 16, red. A. Meissner, Rzeszów 2002.

32 Opieka prawna nad sierotami w Galicji doby autonomicznej, w: Zbirnyk naukowych prac, Do wytokiw stanowlenija ukrainśkoji pedahohicznoji nauky, red. W. Kuź, Umanśkyj Derżawnyj Pedahohicznyj Uniwersytet im. P.Tyczyny, Kyjiw 2002.

33 Udziat społeczeństwa krakowskiego w niesieniu pomocy dzieciom w II połowie XIX i na początku XX wieku, w: „Przegląd Historyczno-Oświatowy” 2004, nr 1-2, R. XLVII 1-2 (183-184), red. M.Walczak, Radom 2004.

${ }_{34}$ Placówki opieki nad dziećmi w Galicji doby autonomicznej, w: Galicja i jej dziedzictwo. Historia wychowania. Misja i edukacja, t. 20, red. K. Szmyd, J. Dybiec, Rzeszów 2008.

${ }^{35}$ Uniwersytet Wakacyjny w Zakopanem jako jedno ze źródet łączności i edukacji kulturalnej Polaków w okresie zaborów, w: Edukacja wobec wielokulturowości; red. M. Jakunowicz, K. Rędziński, Częstochowa $2001 / 2002$.
} 
culi i Łemkowie). Z tego zakresu opublikowała artykuły: Zarys historii szkolnictwa na Huculszczyźnie $w$ XX wieku ${ }^{36}$ i Huculszczynoznawstwo jako forma edukacji regional$n e j^{37}$. Przygotowała także - pod swoją redakcją - pracę zbiorową pt. Huculszczyzna. Kultura i edukacja (Toruń 2009).

W dorobku dr Jolanty Szablickiej-Żak wyróżnić można dwa zasadnicze nurty zainteresowań badawczych. Pierwszy dotyczy szeroko pojętej problematyki szkolnictwa i oświaty w parlamencie II Rzeczypospolitej, drugi - biografistyki. Efektem realizowanych badań są artykuły, dotyczące prac sejmowych nad ustawodawstwem szkolnym i oświatowym oraz kreujących je parlamentarzystów - nauczycieli i działaczy oświatowych w latach 1922-1939 np.: Problematyka szkolna $w$ artykule 13 Konkordatu polskiego z 1925 r. w świetle debaty parlamentarnej ${ }^{38}$, Spory o koncepcje wychowania $w$ debatach parlamentarnych $w$ Drugiej Rzeczypospolitej ${ }^{39}$ i The silhouettes of educational activists in the Parliament of the Second Republic of Poland ${ }^{40}$. Drugi nurt zainteresowan reprezentują noty biograficzne dla słowników i encyklopedii, poświęcone przede wszystkim wrocławskim historykom oświaty i pedagogom, publikowane w Encyklopedii Wrocławia, Encyklopedii pedagogicznej XXI wieku (Warszawa 2003), Stowniku biograficznym polskiej historii wychowania ${ }^{41}$, książce pt. Wrocławskie środowisko akademickie. Twórcy $i$ ich uczniowie 1945-2005 $5^{42}$ oraz pracy redakcyjnej - Ocalić od niepamięci ${ }^{43}$ a także pracy edytorskiej - Na wygnanie do Tarnopola. Wspomnienia Jana Zamorskiego $(1874-1948)^{44}$.

Problematykę szeroko rozumianej aktywności społeczno-kulturalnej i oświatowej społeczności lokalnych Wielkopolski (zarówno polskich, jak i mniejszości narodowych) w okresie międzywojennym podjął dr Mirosław Piwowarczyk. Jego głównym zamierzeniem badawczym jest ukazanie różnorodnych form tej aktywności na tle zmieniających się stosunków społeczno-politycznych, gospodarczych, kulturalnych i uwarunkowań historycznych, kształtujących tę aktywność. W wyniku prowadzonych badań z cy-

${ }^{36}$ Zarys historii szkolnictwa na Huculszczyźnie w XX wieku, w: Wśród ,swoich” i „obcych”. Rola edukacji w społeczeństwach wielokulturowych Europy Środkowej (XVIII-XX w.), red. S. Walasek, Kraków 2006.

${ }^{37}$ Huculszczynoznawstwo jako forma edukacji regionalnej, w: Huculszczyzna. Kultura i edukacja, red. nauk. A. Haratyk, Toruń 2009.

38 Problematyka szkolna w artykule 13 Konkordatu polskiego z 1925 r. w świetle debaty parlamentarnej, w: Katolicka a liberalna myśl wychowawcza w Polsce $w$ latach 1918-1939, red. ks. E.Walewander, Lublin 2000 .

39 Spory o koncepcje wychowania $w$ debatach parlamentarnych $w$ Drugiej Rzeczypospolitej, w: Ideaty wychowania $i$ wzory osobowe narodu polskiego w XIX i XX wieku, red. E.J. Kryńska, Białystok 2006.

40 The silhouettes of educational activists in the Parliament of the Second Republic of Poland, w: Contribution of educational societies to the development of the european culture, edited by E. Sapia-Drewniak, J. Piechnik-Borusowska, Opole 2008.

${ }^{41}$ Stownik biograficzny polskiej historii wychowania, praca zbiorowa pod red. A. Meissnera, W. Szulakiewicz, Toruń 2008.

42 Wrocławskie środowisko akademickie. Twórcy i ich uczniowie 1945-2005, red. A. Chmielewski, W. Glabisz, J. Kmita, Wrocław 2007.

${ }^{43}$ Ocalić od niepamięci, red. J. Szablicka-Żak, Kraków 2002.

${ }^{44}$ Na wygnanie do Tarnopola. Wspomnienia Jana Zamorskiego (1874-1948), red. J. Szablicka-Żak, Nowy Sącz 2008. 
klu Wielkie „Małe Ojczyzny” ukazały się dotychczas dwie monografie: Wielkie „Małe Ojczyzny”. Aktywność społeczno-kulturalna Gostynian w Drugiej Rzeczypospolitej ${ }^{45}$ i Wielkie „Małe Ojczyzny”. Aktywność społeczno-kulturalna polskiej społeczności lokalnej Kalisza w Drugiej Rzeczypospolitej ${ }^{46}$, a także szereg rozdziałów w pracach zbiorowych, m.in.: Rola nauczycieli-regionalistów w aktywizowaniu społeczności lokalnych w II Rzeczypospolitej ${ }^{47}$, Multikulturni zkušenosti lokálnich společenstvi na přikladu Kališe v Druhé Polské Republice ${ }^{48}$, Rola szkót prywatnych $w$ aktywizowaniu małych spoteczności lokalnych w Wielkopolsce w okresie II Rzeczypospolitej (na przykładzie Gostynia) ${ }^{49}$, Aktywność społeczna mniejszości niemieckiej w powiecie gostyńskim w II Rzeczypospolitej ${ }^{50}$, The Importance of local cultural and educational societies in the formation of local environments of Wielkopolska in the Second Republic of Poland (a case study of Gostyn') ${ }^{51}$, Schools not only for Poles. Education for the German minority in Greater Poland in the Second Republic ${ }^{52}$ i The role of regional journals in integrating local communities in Wielkopolska in the Second Republic of Poland ${ }^{53}$.

W szerokim obszarze problematyki badawczej podejmowanej przez dr. M. Piwowarczyka znaczące miejsce zajmują kwestie wychowania i szkolnictwa w okresie II Rzeczypospolitej. Dokumentują to liczne artykuły, wśród których na wyróżnienie zasługują: $E d u$ cational Activity of Akcja Katolicka (Catholic Action) in the Second Republic of Poland ${ }^{54}$,

${ }^{45}$ Wielkie „Małe Ojczyzny”. Aktywność społeczno-kulturalna Gostynian w Drugiej Rzeczypospolitej, Kraków 2006.

46 Wielkie „Małe Ojczyzny”. Aktywność społeczno-kulturalna polskiej społeczności lokalnej Kalisza w Drugiej Rzeczypospolitej, Kraków 2006.

47 Rola nauczycieli-regionalistów w aktywizowaniu społeczności lokalnych w II Rzeczypospolitej, w: Misto historie a úloha učitele dějepisu při formováni multikulturni společnosti, red. J.Vaculik, J.Mihola, Masarykova Univerzita a International Visegrad Fund, Brno 2003.

${ }^{48}$ Multikulturni zkušenosti lokálnich společenstvi na přikladu Kališe v Druhé Polské Republice, w: Multikulturni výchova v teorii a praxi, red. L. Gulová, E. Štěpařová, Brno 2004.

${ }^{49}$ Rola szkót prywatnych $w$ aktywizowaniu malych społeczności lokalnych $w$ Wielkopolsce $w$ okresie II Rzeczypospolitej (na przykładzie Gostynia), w: Funkcja prywatnych szkół średnich w II Rzeczypospolitej: 1918-1939, red. E.J. Kryńska, Białystok 2004.

${ }^{50}$ Aktywność społeczna mniejszości niemieckiej w powiecie gostyńskim w II Rzeczypospolitej, w: Wśród „swoich” 'i ,obcych”. Rola edukacji w społeczeństwach wielokulturowych Europy Środkowej (XVIII-XX wiek), red. S. Walasek, Kraków 2006.

${ }^{51}$ The Importance of local cultural and educational societies in the formation of local environments of Wielkopolska in the Second Republic of Poland (a case study of Gostyn), w: Contribution of Educational Societies to the Development of the European Culture, edited by: E. Sapia-Drewniak, J. Piechnik-Borusowska, Opole 2008.

52 Schools not only for Poles. Education for the German minority in Greater Poland in the Second Republic, w: „Czech-Polish Historical And Pedagogical Journal”. Volume 1, Brno, edited by: J. Němec, Czech Republic 2009.

53 The role of regional journals in integrating local communities in Wielkopolska in the Second Republic of Poland, w: Education and Integrative Processes. Historical and Present Contexts, edited by: M. Piwowarczyk, M. Podgórny, Wrocław 2009.

${ }^{54}$ Educational Activity of Akcja Katolicka (Catholic Action) in the Second Republic of Poland, w: Selected Educational Problems. The Past - the Present - the Future, red. M. Piwowarczyk, M. Podgórny, Kraków 2005. 
Výchova pro budoucnost v pojetí Floriana Znanieckého ${ }^{55}$, Problematyka udostępniania nauki początkowej w języku ojczystym mniejszościom narodowym w Drugiej Rzeczypospolitej $^{56}$, Środki i metody realizacji wychowania obywatelsko-państwowego $w$ szkołach średnich w Drugiej Rzeczypospolitej w latach 1926-1935 (założenia i propozycje) ${ }^{57}$, Instytucjonalne formy opieki nad dziećmi i mtodzieża w Wielkopolsce w II Rzeczypospoli$t e j{ }^{58}$. W dorobku dr. Piwowarczyka warte podkreślenia są także prace redakcyjne, prezentujące stanowiska i dorobek badawczy z zakresu historii edukacji i współczesnych problemów pedagogicznych zarówno polskich, jak i zagranicznych badaczy - Selected Educational Problems. The Past, the Present, the Future (Kraków 2005), Edukacja. Konteksty historyczno-pedagogiczne (Kraków 2007), Education and Integrative Processes. Historical and Present Contexts (Wrocław 2009).

Działalność oświatowo-wychowawcza Związku Pracy Obywatelskiej Kobiet w latach 1928-1939 jest kolejnym realizowanym projektem badawczym M. Piwowarczyka, którego celem jest ukazanie szerokiej działalności oświatowo-wychowawczej ZPOK, w tym roli Związku w rozwoju oświatowym, kulturalnym, cywilizacyjnym, gospodarczym, społecznym i politycznym odrodzonego państwa polskiego oraz jego udziału w realizacji (wspieraniu) polityki państwa w tych obszarach.

W ostatnim dziesięcioleciu znacząco zintensyfikowała się współpraca Zakładu z zagranicznymi ośrodkami naukowymi. W wyniku prowadzonych prac badawczych wzmocniły się kontakty z ośrodkami naukowymi na Litwie, Ukrainie i w Czechach ${ }^{59}$.

W ramach współpracy z Uniwersytetem Pedagogicznym w Wilnie pracownicy Zakładu (S. Walasek, B. Jędrychowska, M. Piwowarczyk) odbywają systematyczne staże naukowo-badawcze, w ramach których prowadzone są kwerendy biblioteczne oraz archiwalne w Litewskim Centralnym Państwowym Archiwum (LCPA) i Litewskim Państwowym Historycznym Archiwum (LPHA). Program współpracy naukowo-badawczej zawiera również nasz udział w konferencjach naukowych i głoszenie wykładów (wykłady z historii Kresów Wschodnich z uwzględnieniem dziejów kultury, szkolnictwa i oświaty dla studentów slawistyki Uniwersytetu Pedagogicznego głosi dr hab. B. Jędrychowska).

Na Ukrainie współpracujemy głównie z Uniwersytetem Lwowskim im. I. Franka (S. Walasek, A. Haratyk, M. Piwowarczyk). Odbywane staże naukowo-badawcze służą

55 Výchova pro budoucnost v pojetí Floriana Znanieckého, w: Proměny pedagogiky, edited by, J. Prokop, M. Rybičková, Praha 2005.

${ }^{56}$ Problematyka udostęniania nauki początkowej w języku ojczystym mniejszościom narodowym $w$ Drugiej Rzeczypospolitej, w: Problematika sociálnich skupin ve výuce společenskovédnich pedet, red. J. Vaculik, J. Němec, Brno 2006.

${ }_{57}$ Środki i metody realizacji wychowania obywatelsko-państwowego w szkołach średnich w Drugiej Rzeczypospolitej w latach 1926-1935 (założenia i propozycje), w: Historyczne konteksty edukacji obywatelskiej w społeczeństwach wielokulturowych, red. A. Szerląg, Kraków 2007.

${ }^{58}$ Instytucjonalne formy opieki nad dziećmi i młodzieża w Wielkopolsce w II Rzeczypospolitej, w: Opieka nad dziećmi i młodzieżą. Studia z dziejów oświaty w XX wieku, red. S. Walasek, Kraków 2008.

59 Współpraca naukowo-badawcza realizowana jest w ramach dwustronnych umów zawartych pomiędzy Uniwersytetem Wrocławskim a Uniwersytetem Pedagogicznym w Wilnie, Uniwersytetem Lwowskim im. I. Franka we Lwowie i Uniwersytetem im.Masaryka w Brnie. 
przede wszystkim przeprowadzaniu kwerend archiwalno-bibliotecznych w Centralnym Państwowym Archiwum Historycznym Ukrainy we Lwowie (CDIAL), Państwowym Archiwum Obwodowym we Lwowie (DALO) i Bibliotece Uniwersyteckiej. Od 2002 r. zintensyfikowała się współpraca naukowa z Katedrą Pedagogiki Uniwersytetu Lwowskiego oraz Naukowo-Metodycznym Centrum „Ukraińska etnopedagogika i narodoznawstwo" Prykarpackiego Uniwersytetu w Ivano-Frankivśku (A. Haratyk).

W omawianym okresie szczególnie dynamicznie rozwijała się współpraca Zakładu Historii Edukacji z Katedrą Historii Fakultetu Pedagogicznego Uniwersytetu im. Masaryka w Brnie. Została ona zainicjowana w 1997 r. przez dr. M. Piwowarczyka i dr J. Szablicką-Żak. Aktualnie współpracą kieruje zespół: prof. dr hab. Stefania Walasek i dr Mirosław Piwowarczyk (ze strony polskiej) oraz prof. dr hab. Jaroslav Vaculik i prof. dr hab. Maria Marečkova (ze strony czeskiej) ${ }^{60}$. Na przestrzeni omawianego okresu, podjęto i zrealizowano wiele inicjatyw naukowo-dydaktycznych, do których zaliczyć należy m.in.:

- realizację międzynarodowego (polsko-czesko-słowackiego) projektu badawczego pt.: Publishing of Brocher from international research into Teaching plans and curriculums of study of history in basic schools of Poland, Slovakia and Czech Republic starting from 1990 (temat realizowano w latach 2000-2001 w ramach Międzynarodowego Grantu Wyszehradskiego - International Visegrad Fund - pod kierownictwem prof. Marii Marečkovej z Katedry Historii Fakultetu Pedagogiki Uniwersytetu im. Masaryka w Brnie);

- wykłady monograficzne realizowane przez badaczy czeskich i polskich: M. Mareckovą, J. Vaculika w Instytucie Pedagogiki Uniwersytetu Wrocławskiego, S. Walasek, M. Piwowarczyka na Fakultecie Pedagogicznym Uniwersytetu im. Masaryka w Brnie;

- publikacje: Misto historie a uloha ucitele dejepisu pri formovani multikulturni spolecnosti, red. J. Vaculik, J. Mihola (Brno 2003), Multikulturni vychova v teorii a praxi, red. L. Gulova, E. Steparova (Brno 2004), Selected Educational Problems. The Past, the Present, the Future, red. M. Piwowarczyk, M. Podgórny (Kraków 2005), Problematika socialnich skupin ve vyuce spolecenskovednich predmetu, red. J. Vaculik, J. Nemec (Brno 2006), Edukacja. Konteksty historyczno-pedagogiczne, red. M. Piwowarczyk (Kraków 2007), Education and Integrative Processes. Historical and Present Contexts, edited by: M. Piwowarczyk, M. Podgórny (Wrocław 2009).

Wspólnym, nowym międzynarodowym przedsięwzięciem wydawniczym jest czasopismo pt. „Czech-Polish Historical And Pedagogical Journal”, którego pierwszy numer ukazał się w lipcu 2009 r. ${ }^{61}$

Bliskie kontakty z ośrodkami naukowymi w Brnie, Wilnie i Lwowie są również okazją do wspólnego organizowania międzynarodowych konferencji naukowych, np. cyklicznych (corocznych) Polsko-Czeskich (Czesko-Polskich) Historycznych Dni. W paź-

\footnotetext{
${ }^{60}$ W skład zespołu wchodzą także: prof. dr hab. Alicja Szerląg, dr Marek Podgórny i prof. dr hab. Jiři

${ }^{61}$ „Czech-Polish Historical and Pedagogical Journal”, Brno 2009, Volume 1, red. J.Němec. W skład komitetu redakcyjnego ze strony polskiej wchodzą: Stefania Walasek, Mirosław Piwowarczyk, Alicja Szerląg i Marek Podgórny.
} Nĕmec. 
dzierniku 2009 r. odbyła się w Brnie jubileuszowa (dziesiąta) konferencja z tego cyklu (4 edycje odbyły się we Wrocławiu), która była rezultatem wieloletniej współpracy naukowo-badawczej i dydaktycznej, z zakresu szeroko rozumianej edukacji, w kontekście historycznym, jak i współczesnym.

Oprócz organizacji „Polsko-Czeskich Historycznych Dni”, przygotowujemy pierwszą edycję cyklicznej konferencji międzynarodowej - „I Polsko-Ukraińskie Historyczne Dni”, które odbędą się 18-19 maja 2010 r. we Wrocławiu pod hasłem „Rozwój polskiej i ukraińskiej myśli pedagogicznej na przestrzeni XIX i XX wieku”. Z inicjatywy Zakładu została zorganizowana w 2001 r. konferencja międzynarodowa pt. „Oświata i szkoła narodów bez państwa w Europie Środkowej i Wschodniej (XIX-XX w.)”. Zakład współorganizował również (w 2005 r.) międzynarodową konferencję zatytułowaną - „Europa wspólnotą narodów. Edukacja międzykulturowa na przestrzeni wieków XIX i XX”. Ponadto uczestniczyliśmy w konferencjach organizowanych w wielu zagranicznych ośrodkach akademickich m.in.: w Tomsku, Kazaniu, Krzemieńcu, Moskwie i Brześciu (B. Jędrychowska), Bratysławie, Wilnie, Brnie i Daugavpils (S. Walasek), Pradze i Brnie (S. Walasek, M. Piwowarczyk), Kijowie, Lwowie, Humaniu, Winnicy, Ołomuńcu (A. Haratyk), a także w ośrodkach akademickich Polski: Białystok, Częstochowa, Gdańsk, Kielce, Kraków, Łódź, Olsztynie, Opole, Poznań, Rzeszów, Warszawa, Szczecin. Tego typu spotkania stanowią okazję do prezentacji własnych badań, są płaszczyznami dyskusji, umożliwiającymi doskonalenie warsztatu badawczego historyka wychowania, a ich wymiernym rezultatem są publikacje naukowe. 